\title{
Ribā (Interest) Between Reason and Revelation in Islam
}

\author{
Saheed Afolabi Ashafa \\ Osun State University, Osogbo, Osun State, Nigeria
}

\begin{abstract}
Article History
Received: December, $7^{\text {th }} 2021$ Revised: December, 23 $2021 \quad$ Accepted: December, $24^{\text {th }} 2021$
\end{abstract}

\begin{abstract}
Corresponding author:

E-mail: saheed.ashafa@unios un.edu.ng

This paper discussed the opposing views of Reason (human intellect) and Revelation (Islamic thought) on the concept and practice of Riba (interest). As it is known that Riba is a universal instrument engaged for economic practices, while revelation, particularly Islam, prohibits it. In this study, arguments from both thoughts are placed side by side using primary and secondary sources. In this regard, the study adopted a descriptive qualitative research design for elucidation. It examined and established the relationship between reason and revelation as well as the areas of departure from each other. The study found out that riba-based economic practice has not been favorable to the course of development across the globe, hence the frequent shift from higher to lower interest rates by various countries. Consequently, Islamic alternatives to Rib $\bar{a}$ were presented with a view to safeguarding the faith and socio-economic status of the adherents of Islam. Research-based recommendations were offered for necessary adjustment by stakeholders. Optimistically, the submission of this study will stimulate a positive response from the stakeholders.
\end{abstract}

Keywords: Islamic Economics, Reason, Revelation, Ribā

\section{Introduction}

The reason relates to human thoughts, while Revelation refers to God's injunctions and verdicts about all matters. Both Reason and Revelation have been issues of debate among philosophers and religious scholars over time, making it a struggle for superiority between philosophy and faith. This does not mean that philosophy is opposed to faith or vice versa, but philosophers have always enjoyed scrutinizing every matter in their way and method. To buttress this stance, Ibn Rushd, as referenced by Mustopa, submitted that there was no conflict between religion and reason, and there was no prohibition in Islam to study philosophy (Mustopa, 2018).

How to cite:

Ashafa, S. A. . (2021). Riba (Interest) Between Reason and Revelation in Islam. Journal of Islamic Economic and Business Research, 1(2), 180-192. https://doi.org/10.18196/jiebr.v1i2.18 
Oke (2003) asserted that philosophy by its method is not aimed at solving problems but asking more questions about the problems of existence. Revelation, on the other hand, is aimed at guiding man towards solving the problems of life so as to attain eternal bliss. In consequence of this fact, Philosophy and Faith (Reason and Revelation) have always addressed issues from different perspectives, even though they sometimes come to convergence. To juxtapose between these thoughts, (Mustopa, 2018) declares that 'even though the human reason has a substantial reach and analytical power, the fact remains that it is still relative and limited because it is unable to reach all the problems faced by humans ultimately.

Based on the age-long debate that has existed between reason and revelation, various issues have been engaged by philosophers. Some of these issues include inspiration \& language, revelation \& morality, God \& evil, secular modernity, to mention just a few. The concern of the present study is an issue of Riba (interest). This is an issue of huge importance about which reason has blatantly occupied a contradictory stance with revelation. More importantly, it is an issue that is central to man's existence because it dwells on his means of livelihood. Over one thousand four hundred years ago, the Almighty Allah forbade Riba (interest) as a means of transaction among humankind. But as if it was never condemned, men continue to make Riba the pivot on which various economies recline. Individual lives on it just as nations depend on it. In fact, it is as if there could be no existence without Riba The fact that Riba is detested and rejected by Allah is not unknown to men. Even the Dictionary of Economics confirms this when it states that "usury was objected to both for exploiting the poor who needed to borrow and for giving a reward unrelated to the productive effort" (Rutherford ,1992).

Despite the fact established above, Rib $\bar{a}$ has continuously enjoyed patronage in the global economic policy. It has been a significant indicator that determines the place of nations in the global economic ladder. It is important to note that disposition to interest (Ribā) has been dictated by the philosophy which perceived money as a commodity. Hence, it is believed that when money is given as a loan, it must yield a return regarded as interest. Against this mindset, developed countries thrive on interest at the expense of the developing ones that continuously depend on the former. In the same manner, the rich exploit the poor on the pretense of engaging in business which makes the latter subservient to them perpetually.

In view of the foregoing, the purpose of the present study is to undertake a comparative analysis of Riba between reason (contemporary economic views) and revelation (shari'ah stance). Through this exercise, various arguments of the opposing thoughts are put forward for analysis with a view to arriving at a beneficial conclusion in order to safeguard the faith of the adherents of Islam within the framework of socio-economic endeavors. Hence, such objectives as a relationship between reason and revelation, evils inherent in $R i b \bar{a}$, an argument for indulging in Riba, as well as possible alternatives to the conundrum of Riba will be discerned in the course of this study. The appropriate recommendation will be offered based on the findings. 


\section{Definition of Terms}

\section{1. $R i b \bar{a}$}

'Rib $\bar{a}$ ' in literal usage has its root as 'rabā' which means among others "to exceed", to be more than", "to increase", and "to grow" (Farah, 2011). With regards to shari'ah, (Ahmad \& Hassan 2007) quoting Al-Jaziri, stated that Ribā refers to "an increase in one or two homogeneous equivalents being exchanged without this increase being accompanied by a return". It is also seen as the surplus income received by a lender over and above the principal amount as a reward for writing or parting with the liquid part of his capital for a specific period of time (Rahman, 1986). (Qutb, 1999) sees 'Riba as the exaction of a charge over and above money owed, which is usually paid out of the sweat and blood of the borrower regardless of whether he profits as a result of the loan or not. The prohibition of Riba is sufficiently discussed in both the Qur'an and the Sunnah of Prophet Muhammad. For instance, Allah forbids the practice of engaging in Riba when in the Qur'an He states that "And their taking of Riba though indeed they were forbidden from it and their devouring the property of people falsely..." (Qur'an 4: 161). Apart from this, many other verses, as would be mentioned shortly, expressed unequivocal condemnation of Ribā. It is equally explicated in the Sunnah of the Prophet. In a narration, Ibn Mas'ud stated that "The Prophet of Allah cursed the eater of Riba and the one who pays it" (Muslim related this). Commenting on this narration, (Uthaymeen, 2004) posits that anyone who pays Riba is cursed for aiding his oppressor to successfully oppress him.

It is pertinent to note that the word ' $R i b \bar{a}$ ' covers both usury and interest in Islamic religion since it condemns any interest rate as wrong. (Gusau, 1995) emphasizes this fact when he asserts that:

Overwhelming majority of Islamic jurists and economists today conceded to the fact that all forms of interest and usury are riba whether compound or simple, large or small, and so are absolutely prohibited in Islam.

In fact, every sum stipulated to be received or given over and above what one advances or receives as a loan is a usury or interest whether the dealing is with an individual or with a bank or with any other institution. Riba is not confined to money but all kinds of commodities in which there is an idea of stipulated increase when taken or given in loan. For this reason, riba is said to be of two types: Ribā al-nasiah (interest in trade) and Riba alfadl (interest in barter (Ahmad \& Hassan, 2007).

At this juncture, it is appropriate to clarify that the use of the word Riba to indicate bribery as commonly employed by the Yoruba-speaking people of Southwest Nigeria is wrong. Bribery has its own Islamic term as 'rishwah'. It is an item offered or promised to be offered to someone in other to influence or persuade him to do something in favor of the giver (Doi 1984). In Islam, those concepts are different from each other though they are both forbidden in sharia.

'Rib $\bar{a}$ in the contemporary western economic system has various terminologies such as 'exact interest', 'compound interest', 'fixed interest', 'simple interest' to mention just a few, each of which refers to a type and method of charging the fee on a borrower for the use of 
the borrowed money. It is worthy of note, however, that Islam condemns all these forms of interest. For instance, it could be deduced from the definition offered by Sayyid Qutb, as

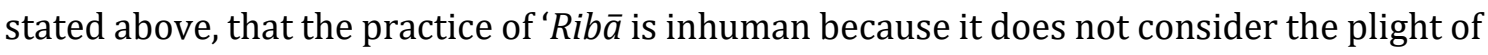
the borrower and may sometimes aggravate his hardship if there is a loss in the corresponding venture. Based on this framework, the position of revelation will be expounded under the section of 'revelation on Riba.

\subsection{Reason}

According to Longman Dictionary of Contemporary English, reason means "to form a particular judgment about a situation after carefully considering the facts". The Encyclopedia of religion sees reason as "the human capacity for seeing, forming and investigating cognitive relations". Reason in philosophy is an active human mental capacity for knowing the truth. As opposed to faith, Reason seeks the truth in intellectual proofs rather than divine authority; as opposed to sensation, it arrives at knowledge through logical principles and deduction (Benton, 1974). Similarly, reason as a philosophical concept shows great concern for thinking, understanding, and contemplating, all of which are principally actions of the mind (Mustopa, 2018). The reason is equally described as having the quality of non-permanence. Hence, it can change. Based on this description, reason can be good or evil, and it can be beneficial or harmful (Churchman, 1968). From the foregoing, one can infer that Reason is the wisdom displayed with the intellect. It is also important to emphasize that reason is the phenomenon peculiar to man as different from God. More so, reason as a concept is popular among philosophers. The classical rationalists of the west, Plato and Aristotle, and their medieval disciples re said to understand everything to be accessible to reason (Eliade, 1987). Therefore, Reason may be said to be the human answer to an issue after a thorough examination of the underlying factors. It is pertinent to note that being a human implies all sorts of inherent limitations. It will not be out of place to state that Islam acknowledges the significance of reason in facilitating comprehension of matters, including religious facts. To this end, several verses of the Qur'an extols reason and people of reasoning and as well condemn those who do not reflect nor reason. Qur'an says, "He grants Hikmah (wisdom) to whom He pleases and he, to whom Hikmah is granted is indeed granted abundant good. But none remember except men of reasoning", (Qur'an 2: 269). Also, it states that "Verily, the worst of living creatures with Allah are the deaf and the dumb, who reason not" (Qur'an 8: 22). From this last quotation, deafness and dumbness are used metaphorically to indicate their inability to utilize their senses for effective and productive activities. Accordingly, Mustopa posits that reason as a concept cannot be reliable on absolute religious matters. This fact is particularly instructive to the focus of this study.

\subsection{Revelation}

Revelation is a concept mostly related to religion. It is a religious term that designates the disclosure of divine or sacred reality or purpose to human beings. Such disclosure may come through mystical insights, historical events or spiritual experiences that transform the lives of individuals and groups (Benton, 1974). Revelation is also seen as the work of God by which he makes known to human being those things about himself that they could not know in any other way (Brasher, 2001). The means by which God makes Himself is known to all 
people everywhere, through the natural world, the miraculous and providential events of history, and the nature and constitution of man constitute the general revelation (Brasher, 2001). In Islam, revelation comes to man through the prophets of Allah. The merciful and loving has sent many prophets at many times in history. All the prophets of Allah were men of good character and high honor. They were prepared and chosen by Allah to deliver His message to mankind. The prophetic message is divinely inspired by revelation and the command of Allah, the Most High (Sabuni, 2007). The learned Shayk Abul Hassan al-Nadwi says:

The first and foremost difference between the prophets and other leaders is that the knowledge, mission and message of the prophets are neither the formulation of their incisive intelligence, intuition nor wisdom, nor reaction to the horrible conditions in which the prophets are born and spend their lives. Their preaching is always divine revelation, the messages communicated from high for which they are specially selected (Sabuni, 2007).

The revelation could be delivered in three modes; they are; wahy (inspiration) which is a hasty suggestion thrown into the heart of a man under the influence of the Holy Spirit. In this case, a related idea is illuminated as if by a flash of lightning. It is not a message in words but an idea that clears up doubt or difficulty. The second mode, which is ru'yah (dream) or kashf (vision), refers to sights seen when asleep or in a state of trance. In contrast, the third mode is by sending a messenger. The messenger here is Jibril (Gabriel), the Archangel, who carried divine messages to the prophets. This kind of revelation is said to be the highest form of revelation (Abdul, 1971). The Quran confirms this mode when it states:

And it is not (vouchsafed) to a mortal that Allah should speak to him except by revelation or from behind a veil or that He sends a messenger to reveal whatsoever He will by his leave (Quran 42: 5)

Therefore, Quran is a revelation that is full of wisdom and truth. It contains the best of philosophy and the choicest of law for human civilization. It points out the right path and guides man to success and salvation. Revelation is meant to guide humanity in all affairs of the two worlds; this life and the hereafter.

\subsection{Nexus between Reason and Revelation}

It is necessary to point out that reason, as it appears, does not actually connote a parallel view as an individual concept. Rather, it is an instrument that aids the understanding of man in discovering and applying the truth(s) from other sources, including revelation. Consequently, intellect $(a q I)$ is confirmed as the best of gifts that are conferred by God, the author of revelation to man (Qur'an 2: 269). With this precious gift, man is able to reflect, reason, understand and believe, (Q2: 164, Q5: 58, Q10: 100).

Revelation as a product of religion has always advocated the use of reason and also acknowledges the use of reasoning in propagating the message of revelation. The Quran states, "invite to the way of your lord with wisdom and fair preaching, and argue with men in a way that is better". (Quran 16:125) 


\section{Ribä (Interest) Between Reason and Revelation in Islam \\ Saheed Afolabi Ashafa \\ Page: 180-192}

The question of which verdict should be upheld in time of conflict between Reason and Revelation has been an age-long argument among scholars. A prominent scholastic theologian Imam al-Ash'ari (260/330 A.H), did not only articulate his disagreement with the rationalists but also powerfully explained the inadequacies of adopting rationalism as an ideology for the advancement of the truth. To Ash'ari, rationalism led neither to the acquisition of certain knowledge nor to the eternal truth, and rather he considered that it led to greater doubt and contradictions. He, therefore, concludes that real knowledge is applied only to the recognition and acceptance of revelation as the only means to reach eternal truth because the only ultimate source of truth is God himself (Ahmad, 2004).

On the other hand, a rationalist school of thought in Islam known as Mu'tazilah on their path did not reject revelation, though, emphasizing that the real message of revelation could not be properly understood without the use of reasoning faculty. Thus, they gave reason preference over and above revelation. And that whenever the two appear to clash, rationalistic understanding must prevail, not as an alternative to revelation but as a genuine clarification of the revealed message. To Ibn Rushd (known in the West as Averroes), a Spanish Muslim philosopher revealed truth should be accepted as such, and the knowledge gained from observation and experiment should be accepted for what it is. They are treated separately as they express parallel realities. Similarly, Ibn Taymiyya views the issue of reason and revelation as a struggle between 'Knowledge' and 'Conjecture'. Hence, the scripture (revelation) validates and approves the truth, which is knowledge, while a conjecture that is non-validated by the scripture is not necessarily approved by reason. This argument holds that reason is not necessarily opposed to revelation if the former is objective. (El-Tobgui, 2018). Knowledge, in this sense, is seen as a product of reason which is guided by the inherent effect of revelation. This perception underscores the relationship. It confirms the inseparability of the two concepts. According to (Muhibbu-Din, 2008), the three levels with which perception takes place are the spiritual, the intellectual and the sensory levels. He explains that the spiritual level deals with revelation, the intellectual deals with the cognitive process of thinking, and the sensory deals with observation. From this argument, it is clear that both the revelation and reason are put to action for certainty to take place.

In relation to the above, al-Kindi (d. 260 AH/873C.E), a leading Muslim Philosopher, as quoted by (Muhibbu-Din, 1991), justified the accord between Reason and Revelation on three grounds thus: (i) that Revelation is part of Reason (ii) that the prophet's revelation and philosophical truth are in accord with each other and (iii) that the pursuit of theology is logically ordained.

To sum it up, all the contributors to the argument agree that revelation is a distinguished instrument for discerning the truth and that revelation is for the purpose of guidance. Therefore, we can further deduce that.

1. God, the author of revelation, is the creator of reason

2. Though the reason is the best of the properties handed down to man, it has its limitations. 


\section{Ribä (Interest) Between Reason and Revelation in Islam \\ Saheed Afolabi Ashafa \\ Page: 180-192}

3. The scope of revelation transcends the limits of reasons.

4. Hence, revelation is superior to living and should be held as such

\subsection{Reasons Advanced for Rib̄a}

Various accounts given as the reason for indulging in Riba (interest) include compensation for the lender who has been denied the opportunity to use the wealth for personal consumption. The economists capture this principle under what they call 'abstinence theory'. This theory says that interest is the reward that accrues to the lender for parting away with his liquidity, compensation for waiting or delayed consumption or sacrifice of savings. Rutherford (1992) contends that: "as the lender has to abstain from current consumption to make the loan, he should be compensated". (Jhingan, 2007) also expresses this view when he says, "interest is remuneration for mere abstinence.

Another reason advanced for charging interest is the 'time value for money.' It is believed that an amount at one time is not the same value in the future. Therefore, it is a risk on the path of the lender, who will most likely be affected if the money devalues. (Bello, 2004) does agree with this fact when he states that; the interest account for the time value and covers the probable loss that would be incurred by the lender."

Value of capital productivity is also a reason adduced for the charge of interest. This theory posits that all the four factors of production are entitled to reward; therefore, as land attracts rent, labor attracts wages, and entrepreneur attracts profit, so is capital entitled to interest. Jhingan (2007) justifies this argument when he declares that "interest is the income which goes to the owner of the capital." riba (interest) is also charged to cater for operational cost since the latter is inevitable. In this case, interest is seen as the reward for management since the lender has to incur expenditure in keeping account of the borrowers.

\subsection{Revelation on Riba}

(Chapra, 2007) declares that four of the world's major religions (Judaism, Christianity, Hinduism and Islam) having a following of more than two-thirds of the world have prohibited interest. From the Islamic perspective, interest is condemned in an unequivocal manner which is an indication that its evil is enormous and disastrous. Allah gives a warning thus; "And that which you give to others in order that it may increase your wealth by expecting to get a better one in turn from other people's property has no increase with Allah" (Quran 30:39).

Also, the Quran says: "O you who believe! Eat not Ribā doubled and multiplied, but fear Allah that you may be successful." (Q3:120)

There are other sets of verses as could be seen in Quran chapter 2 verses $275,276,278$, and 279 , but for limited space, it could be mentioned that prohibition of Riba is undoubtedly quite strict and decisive, which is an indication that its effect is greatly detested by Allah. It should quickly be pointed out that interest is exploitative and an act of wickedness to the needy. A borrower only takes a loan for lack of option and probably for reason of distress. Sayyid Qutb (1999), while commenting on verses of Quran chapter two (verses quoted above), opines that "Usury is usually paid out of sweat and blood of the borrower, regardless 


\section{Riba- (Interest) Between Reason and Revelation in Islam \\ Saheed Afolabi Ashafa \\ Page: 180-192}

of whether the involved parties profit from the loan". It is important to note that inflation which is a bane to the economy, is largely caused by Rib $\bar{a}$. A related study (Onyido, 1997) corroborated this tendency when he asserts that borrowers are willing to borrow when it is realized that goods purchased through the loan will appreciate by a factor of their expected inflation.

From another angle, people still think that Riba or loan transaction is a business; however, Allah does not approve of this form of transaction. Such claim has been allayed by the Quran when Allah says: "...That is because they say "trading is only like Riba whereas Allah has permitted trading and forbidden riba ... Allah will destroy Riba and will give increase for deed of charity...." (Quran 2; 275-276). It is against this thought that the Qur'an emphasized Allah's ownership of wealth (QS 57:7). As such, Islam does not view capital as being entitled to return except through lawful trade. Money is not a commodity that should attract interest. (Shahar, Shahar et al., 2017) stressed that Islam recognizes capital as a factor of production, but it does not allow it to make a predetermined claim on the productive surplus in the form of interest.

Similarly, there is a sharp contrast between interest and profit since the latter is not a predetermined rate of return and has a probability of loss. Therefore, profit is lawful and worthwhile, whereas interest is not the same as profit. In order to remove all doubts, Allah further declares in another portion thus: "O you who believe! Eat not each other's property among yourself by wrong means except it be a trade among you true mutual goodwill..." (Quran 4:29). It has been established that al Riba oriented transactions do not consider the risk that might afflict money lenders. This blatant selfishness is highly condemnable.

To further elaborate the position of revelation on the evil which Ribā portends for society, it is important to state that modern society does not compel anyone to save as to indicate abstinence from such fund as argued. It is therefore based on a false psychological premise. The interest (riba) rate justified on the basis of value productivity does not consider the uncertainty and other risk factors in the market; hence, there is no guarantee that every capital has a positive return.

Furthermore, it is important to establish that western economists are aware that interest rate has a negative effect on the economy in particular and on society at large in general. In a practical experience of Nigeria as a country, a former president, Olusegun Obasanjo, once lamented the plight of the country resulting from the interest rate. (Alaro, 2021) quoted the former president thus:

All that we had borrowed up to 1985 or 1986 was around $\$ 5$ billion and we have paid about $\$ 16$ billion, yet we are still being told that we owe about $\$ 28$ billion. That $\$ 28$ billion came about because of the injustice in the foreign creditors' interest rates. If you ask me what is the worst thing in the world, I will say it is interest.

In fact, the Keynesian theory of interest rate implies that low-interest rate as a component of cost funds encourages borrowers for investment (Onyido, 1997). In other words, investment is at its best when the interest rate is at zero. Against this background, it has been observed that various nations are not comfortable with high-interest rates since it is 
not friendly with economic growth, just as it also hinders societal development. Below is the presentation of a mass shift of selected nations of the world from a relatively high-interest rate to a lower rate.

Table 1. Interest rate of selected countries as of May 2021

\begin{tabular}{ccc}
\hline Country/ central bank & Current interest & Previous interest \\
\hline Egypt & $9.25 \%$ & $10.0 \%$ \\
South Africa & $3.5 \%$ & $3.7 \%$ \\
Australia & $0.1 \%$ & $0.25 \%$ \\
India & $4.00 \%$ & $4.4 \%$ \\
Japan & $-0.1 \%$ & $0.0 \%$ \\
New Zealand & $0.2 \%$ & $1.0 \%$ \\
Taiwan & $1.25 \%$ & $1.5 \%$ \\
Czech Republic & $0.25 \%$ & $1.00 \%$ \\
Hungary & $0.6 \%$ & $0.7 \%$ \\
Ice land & $4.25 \%$ & $13 \%$ \\
Norway & $0.0 \%$ & $1.5 \%$ \\
Poland & $0.1 \%$ & $0.5 \%$ \\
Slovakia & $1.72 \%$ & $2.75 \%$ \\
Sweden & $0 \%$ & $0.2 \%$ \\
Switzerland & $-0.7 \%$ & $-0.5 \%$ \\
United Kingdom & $0.1 \%$ & $0.25 \%$ \\
Turkey & $6.25 \%$ & $9.75 \%$ \\
Canada & $1 \%$ & $0.5 \%$ \\
USA & $0.25 \%$ & $1.25 \%$ \\
Brazil & $2.75 \%$ & $3.5 \%$ \\
Nigeria & $11.5 \%$ & $9.75 \%$ \\
\hline
\end{tabular}

Source: https://www.global-rates.com

Equally, close observation of the table shows that the world's leading economies are those with lower interest rates. It has also been noted that these nations are mostly concerned about bringing down the interest rates for better economic performance. In the final analysis, one would discover that interest simply confines wealth to circulate among the rich at the expense of the poor who continue to borrow. It thus brings nothing but misery and suffering for individuals, communities and nations, while it benefits only a few money lenders.

Other resultant effects of an interest-based system are unemployment, prostitution and robbery since the wealth of the rich have been confined as loan-able funds instead of being invested for the benefit of all.

\subsection{Islamic Alternatives to Ribā (Interest)}

There are a number of reasons why Riba is introduced to the economic system in the entire human endeavor. To each of these transactions, Islam provides an alternative in order to escape the trap of Riba as well as to avoid the wrath of Allah. Some of these alternatives, as discussed by (Raimi, Bello et al., 2010), are:

1. Mudārabah (Capital Financing): This is a profit/loss tool where banks or individuals with financial power supply capital required for businesses while the other party or 
customer gives time and expertise, which forms a relationship between the supplier of capital and users of capital. Both parties would share profits and losses as agreed in the contract terms.

2. Mushārakah (Partnership Financing): In this case, the parties contribute capital jointly and also contribute managerial expertise, time and other essential services at agreed percentages or proportion. The profit or losses are shared according to the terms of a contract binding them.

3. Murābaha (Sale for Mark-up): This is a contract in which a client wishes to purchase equipment or goods requests an Islamic bank to purchase the items and sell them to him at cost plus a declared profit.

4. Qard Hassan (Good Loan): Literally, it means good loan. In Islamic jurisprudence, it refers to micro-credit or large credit devoid of interest given to an individual by fellow Muslims, commercial banks, cooperative societies, investment clubs and corporate organizations for the purpose of empowerment and poverty reduction.

5. Al-ijāra (Leasing): This is an agreement under which an Islamic bank leases equipment or building to a client against an agreed rental payment.

These financial tools and some others have been generally adopted in the Islamic economic industry as means of lawful transactions and alternatives to interest-bearing modes of transactions. (Warninda, 2013) confirms that Mudārabah and Mushārakah have a stronger positive influence on the profitability of Islamic banks, while Abubakar, Garba \& Suleiman (2020) ascertained that investment in Sukuk and Ijārah assets have a positive impact on the financial performance of Islamic finance.

\subsection{Differences Between Ribā and Interest-Free Modes of Financing}

From the line of this discourse, it is clear that Ribā is a product of man's intellectual prowess. It is therefore capable of error since man is not perfect. On the other hand, interest-free instruments are products of shari'ah which are principally divine-oriented. Due to this distinct demarcation, differences are not out of place. The following are the visible distinctions in the two systems:

a. Faith-Based: The primary difference between $R i b \bar{a}$ and the interest-free system is the latter's source is sharia. The foundation of Islamic economic institutions is the Islamic faith. It must reflect compliance with shari'ah in all its styles and modes of operation. This account for the reason why there is a limitation to the transactions which Islamicoriented transaction can engage. The Qur'an states that: "O you who believe! Eat not each other's property among yourselves by the wrong means except it be a trade among you through mutual goodwill..." (Qur'an 4: 290.

b. Partnership and Brotherhood: Partnership is defined as the relationship between persons carrying on a business in common with a view of making a profit (Longe, 2001). Brotherhood is a bond that is established based on love and mutual cooperation. While partnership exists in the conventional economic practice, brotherhood is a practice 
established as an obligation in Islam. Hence, in the economic practice of Islam, showing concern for the well-being and success of others are a tenet that must be observed.

c. Profit and Loss Sharing (PLS): In Riba -based system, the lender who is seen as an investor is assured of a pre-determined interest rate. In the interest-free system of Islam, risk-sharing is the guiding principle between the provider of capital and the user of funds. Here, there is equality and a sense of commitment on the part of all partners.

d. Principle of Justice: Justice is central to the Islamic faith. It features in all aspects of human life, including the economic system. For instance, the concepts of 'share the profit', 'share the losses' are all about establishing justice. Also, Zakat, Sadaqah, \& Qard Hasan are all means of wealth redistribution from the wealthy to the vulnerable to emphasize the justice of Allah.

\section{Conclusions and Recommendation}

This study has contextualized Riba (interest) in the debate between Reason and Revelation with a view to establishing the wisdom behind the prohibition of Riba by the divine law. It was acknowledged that human intellect (' $a q l$ ) is a vital tool to discern divine messages and to facilitate a better understanding of the same. It is not, however, superior to the revelation on the basis that the author of revelation is the one that endows reasoning and knows better in all matters.

Although it has been argued that Riba possesses certain benefits in the economy based on human reasoning, the fact remains that it is a forbidden practice as ordained by the sources of shari'ah. Proponents of Riba -based economy believe that Riba is charged to compensate the lender who made his wealth available for others to use. They equally argue that resources (money) provided as loans might have lost their value in the future. Hence additional charge should cover the anticipated decrease in value. They as well believe that giving out capital for business should attract a fee.

On the other hand, it is established that indulgence in Riba or Rib $\bar{a}$-based activities is a gross violation of Qur'anic injunction. Sequel to this fact, certain evils are inherent in such acts once it is forbidden by divine law. It has been proved to be an exploitation of the poor and needy because wealth originally belonged to the Creator. Indulgence in Rib $\bar{a}$ is confirmed to make people complacent and redundant since they will be waiting for the borrower to bring return no matter the condition and the circumstance. Inflation and recession are basically induced by Rib $\bar{a}$-based system of economy. Islam does not perceive money as a commodity that should be transacted as an item of merchandise. More importantly, Ribā is prohibited from achieving fairness and economic welfare among humanity.

In view of the various arguments unraveled in the foregoing discussion, the following recommendations are hereby offered for a better socio-economic endeavor in society. Muslim scholars should embark on sensitization of people on the evil inherent in Riba . This is to create awareness of Allah's law in the people in order to prepare them for a pragmatic approach. Muslim communities in various professional groups should establish noninterest cooperative societies to serve the Muslims so as to have the experience of the 
interest-free institution. In addition, academic courses on Islamic economics and related fields should be introduced at all levels of our higher education so as to raise the awareness and consciousness of Muslim students in an interest-free economy.

Banks should de-emphasize interest-based transactions and focus on other businesses which are not only lawful but also profitable. It is equally deemed necessary that more interest-free banks should be established by the apex bank of various nations, especially where there are very few or none in existence.

\section{References}

Abdul, M. O. A. (1971). The Holy Book of Islam, It's Content and Value (an Introduction to the Study of the Qur'an). Lagos, Islamic Publication Bureau.

Ahmad, A. U. F. and M. K. Hassan (2007). "Riba and Islamic banking." Journal of Islamic Economics, Banking and Finance 3(1): 1-33.

Ahmad, M. T. (2004). Revelation, Rationality, Knowledge and Truth. United Kingdom, Islam International Publication Limited. .

Alaro, A. R. A. (2021). Islamic Financial Services: The Interplay of Religion, Law and Corporate Social Responsibility. Ilorin, University of Ilorin.

Bello, F. O. (2004). Application of Mathematics and Statistics to Finance. Lagos, Micheltos Prints.

Benton, W. S., C. (1974). The Encyclopedia Britannica. P. W. Goetz. Chicago, Encyclopedia Britannica Inc.: 783.

Brasher, B. E. (2001). Encyclopedia of Fundamentalism. New York, Routledge: 417-418.

Chapra, M. U. (2007). "The case against interest: Is it compelling?" Thunderbird International Business Review 49(2): 161-186.

Churchman, C. W. (1968). Challenge to reason, McGraw-Hill New York.

Dewi Warninda, T. (2013). "Dynamic Model of Islamic Bank Profitability." Journal of Islamic Banking \& Finance 30(2).

Doi, A. R. (1984). Shari'ah: The Islamic Law. London, Ta Ha Publishers.

Eliade, M., and Adams J. et al (1987). The Encyclopedia of Religion. New York, Macmillan Publishing Company. 2: 223.

El-Tobgui, C. S. (2018). "Ibn Taymiyya on the Incoherence of the Theologians' Universal Law: Reframing the Debate between Reason and Revelation in Medieval Islam." Journal of Arabic and Islamic Studies 18: 63-85.

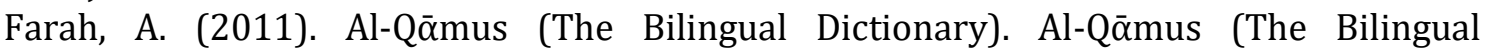
Dictionary). A. Farah. Lebanon, Dar al-Kutub al'Ilmiyah.

Gusau, S. A. (1995). Readings In Islamic Economics. Sokoto, Usmanu Danfodiyo University. Jhingan, M. L. (2007). Micro Economic Theory. Delhi, Vrinda Publication Ltd.

Longe, O. A. (2001). Schools Essential Commerce for Senior Secondary. Lagos, Tonal Publishers.

Muhibbu-Din, M. A. (1991). "Revelation and Reason in Islam." LASU Journal of Humanities, The Journal of the Faculty of Arts and Social Sciences 2(1\&2): 30.

Muhibbu-Din, M. A. (2008). Islam and Science: Historical Context and Modern Challenges. Lagos, Lagos State University, Ojo, Nigeria.

Mustopa, D. (2018). "Integration of Reason and Revelation in the Perspective of Philosophy of Science." International Journal of Nusantara Islam 6(2): 175-181.

Oke, S. (2003). "'Scope, Definitions and Problems of Philosophy" in A. O. K. Noah (ed), Fundamentals of General Studies." 391.

Onyido, B. C. (1997). "Interest rate policies in ECOWAS countries: a comparative analysis." Bullion 21(4): 4. 
Qutb, S. (1999). In the Shade of the Quran. United Kingdom, The Islamic Foundation.

Rahman, A. u. (1986). Encyclopedia of Seerah. Encyclopedia of Seerah. London, Seerah Foundation: 570.

Raimi, L., M. A. Bello and H. Mobolaji (2010). "Faith-based model as a policy response to the actualisation of the millennium development goals in Nigeria." Humanomics 26(2): 124-138.

Rutherford, D. (1992). Dictionary of Economics. New York, Routledge Publishers: 479.

Sabuni, M. A. (2007). Prophethood and the Prophets. Beirut, Al-Maktabah Al-Assriyah.

Shahar, W., W. S. S. Shahar, N. M. Puad, N. J. Rafdi, S. W. S. A. Sanusi and W. S. W. Hassin (2017). The Historical Development of Islamic Banking. 4th International Conference on Management and Muamalah. Putrajaya: ICoMM.

Uthaymeen, M. S. (2004). Sharhu Riyadh as-Salihin Min Kalōmi Sayyidi al-Mursalin. Cairo, Dar al-Fajri Liturath. 